\title{
Canadian home total parenteral nutrition registry: Preliminary data on the patient population
}

\author{
Maitreyi Raman $M D^{1}$, Leah Gramlich $M D^{2}$, Scott Whittaker $M D^{3}$, Johane P Allard $M D^{1}$
}

\begin{abstract}
M Raman, L Gramlich, S Whittaker, JP Allard. Canadian home total parenteral nutrition registry: Preliminary data on the patient population. Can J Gastroenterol 2007;21(10):643648.
\end{abstract}

BACKGROUND: Long-term administration of home total parenteral nutrition (HTPN) has permitted patients with chronic intestinal failure to survive for prolonged periods of time. However, HTPN is associated with numerous complications, all of which increase morbidity and mortality. In Canada, a comprehensive review of the HTPN population has never been performed.

OBJECTIVES: To report on the demographics, current HTPN practice and related complications in the Canadian HTPN population.

METHODS: This was a cross-sectional study. Five HTPN programs in Canada participated. Patients' data were entered by the programs' TPN team into a Web site-based registry. A unique confidential record was created for each patient. Data were then downloaded into a Microsoft Excel (Microsoft Corp, USA) spreadsheet and imported into SPSS (SPSS Inc, USA) for statistical analysis.

RESULTS: One hundred fifty patients were entered into the registry (37.9\% men and $62.1 \%$ women). The mean $( \pm$ SD) age was $53.0 \pm 14$ years and the duration requiring HTPN was $70.1 \pm 78.1$ months. The mean body mass index before the onset of HTPN was $19.8 \pm 5.0 \mathrm{~kg} / \mathrm{m}^{2}$. The primary indication for HTPN was short bowel syndrome (60\%) secondary to Crohn's disease (51.1\%), followed by mesenteric ischemia (23.9\%). Complications: over one year, $62.7 \%$ of patients were hospitalized at least once, with $44 \%$ of hospitalizations related to TPN. In addition, $28.6 \%$ of patients had at least one catheter sepsis (double-lumen more than single-lumen; $\mathrm{P}=0.025$ ) and $50 \%$ had at least one catheter change. Abnormal liver enzymes were documented in $27.4 \%$ of patients and metabolic bone disease in $60 \%$ of patients, and the mean Karnofsky score was 63 .

CONCLUSIONS: In the present population sample, the data suggest that HTPN is associated with significant complications and health care utilization. These results support the use of a Canadian HTPN registry to better define the HTPN population, and to monitor complications for quality assurance and future research.

Key Words: Complications; Demography; Nutrition; Parenteral; Registry

Tong-term administration of home total parenteral nutrition L(HTPN) has permitted patients with chronic intestinal failure due to massive resection or underlying disease to survive for prolonged periods of time. The point prevalence of HTPN patients varies widely, ranging from 0.65 patients per one million inhabitants in the Spanish population to 12.7 patients per one million inhabitants in Denmark (1). In the United States

\section{Registre de patients sous alimentation paren- térale totale à domicile au Canada : Données de population préliminaires}

HISTORIQUE : L'administration prolongée de leur alimentation parentérale totale à domicile (APTD) a permis aux patients atteints d'insuffisance intestinale chronique de survivre pendant des périodes appréciables. Par contre, l'APTD est associée à de nombreuses complications qui contribuent à accroître la morbidité et la mortalité. Au Canada, aucune analyse systématique n'avait encore porté sur les patients sous APTD.

OBJECTIFS : Faire le point sur les données démographiques, les pratiques courantes et les complications de l'APTD auprès de la population actuellement sous APTD au Canada.

MÉTHODES : Il s'agit d'une étude transversale à laquelle cinq programmes d'APTD ont participé au Canada. Les données sur les patients ont été consignées par les équipes des différents programmes dans un cyber-registre sur le Web. Un dossier confidentiel unique a été créé pour chaque patient. Les données ont ensuite été téléchargées dans une feuille de calcul Microsoft Excel (Microsoft Corp., É.-U.) et importées sous forme de fichiers SPSS (SPSS Inc., É.-U.) pour analyse statistique.

RÉSULTATS : Cent cinquante patients ont été inscrits au registre (37,9\% d'hommes et $62,1 \%$ de femmes). Lâge moyen ( \pm É. $-T$.) était de 53,0 \pm 14 ans et l'APTD était requise chez ces patients depuis 70,1 $\pm 78,1$ mois. L'indice de masse corporelle moyen avant le début de l'APTD était de $19,8 \pm 5,0 \mathrm{~kg} / \mathrm{m}^{2}$. La principale indication de l'APTD était le syndrome de l'intestin court (60\%) secondaire à la maladie de Crohn (51,1\%), suivie de l'ischémie mésentérique (23,9\%). Complications : Au cours d'une année, $62,7 \%$ des patients ont été hospitalisés au moins une fois, $44 \%$ de ces hospitalisations ayant été associées à l'APTD. De plus, 28,6 \% des patients ont présenté au moins une infection de leur cathéter (infections plus fréquentes avec les cathéters à double lumière vs simple lumière; $\mathrm{p}=0,025)$ et $50 \%$ ont dû faire chan-ger leur cathéter au moins une fois. Des taux d'enzymes hépatiques anormaux ont été notés chez $27,4 \%$ des patients et la maladie osseuse métabolique chez $60 \%$ des patients; l'indice de Karnowsky moyen a été de $63 \%$.

CONCLUSION : Pour l'échantillon de population actuel, les données suggèrent que l'APTD est associée à des complications importantes et à une augmentation de l'utilisation des soins de santé. Ces résultats appuient l'utilisation d'un registre d'APTD au Canada pour mieux définir la population sous APTD et pour vérifier les complications à des fins d'assurance de la qualité et de recherche éventuelle.

(US), between 1982 and 1992, the estimated prevalence of patients receiving HTPN was 120 per one million people (2). Outcome profiles $(2,3)$ indicate that most of these patients received HTPN for only a few months, but $20 \%$ required support for more than one year. Although the number of people in the US who received long-term HTPN appears small, their chronic dependence on HTPN makes them major users of

${ }^{1}$ University Health Network, Toronto, Ontario; ${ }^{2}$ University of Alberta, Edmonton, Alberta; ${ }^{3}$ University of British Columbia, Vancouver, British Columbia

Correspondence and reprints: Dr Johane P Allard, The University Health Network, The Toronto General Hospital, 200 Elizabeth Street,

9NU-973, Toronto, Ontario M5G 2C4. Telephone 416-340-5159, fax 416-348-0065, e-mail johane.allard@uhn.on.ca

Received for publication August 17, 2006. Accepted January 29, 2007 
TABLE 1

Indications for home total parenteral nutrition $(n=140)$

\begin{tabular}{lc}
\hline Indication & Prevalence, \% \\
\hline Short bowel syndrome & 65.7 \\
Pseudo-obstruction & 15.0 \\
Mucosal disease & 7.9 \\
Fistula & 2.1 \\
Cancer & 7.1 \\
Unexplained nausea and vomiting & 1.4 \\
Mechanical obstruction & 0.7
\end{tabular}

health care services, especially for central line complications. This life-saving therapy is associated with numerous complications, including metabolic, infectious and mechanical complications, TPN-related liver disease, metabolic bone disease (MBD), catheter sepsis and occlusions (4), all of which can increase morbidity and mortality in this patient population.

In both the US and Europe, several groups $(2,5,6)$ have investigated the clinical outcomes of patients on HTPN. However, in Canada, a comprehensive review of the HTPN patient population has never been performed. This may be due to the fact that data capture is performed purely on a voluntary basis with minimal compensation for time and effort, and that considerable coordination is required among multiple centres. There are an estimated 400 patients receiving HTPN in Canada. HTPN is usually provided through provincial hospital-based programs with interaction with home care services. Usually, TPN solutions and supplies are provided by one designated company. There are several HTPN programs in Canada, and there are a variable number of centres per province.

Considering that HTPN is an expensive therapy with potential complications, a Canadian HTPN registry was created. The objective of this registry was to prospectively collect, over the next six years, pertinent demographic and clinical data on the HTPN population in Canada, and to determine the factors affecting survival, complications and TPN dependency, as well as to document the current practice of HTPN administration for quality assurance purposes. This Canadian HTPN registry is the only method capturing this information on HTPN patients in Canada, and data on this population have never been published. Hence, the present study presents original data.

For the present cross-sectional study, the objective was to collect pertinent demographic and clinical data, and to document the current HTPN practice and related complications in the first 150 patients entered in the registry. More programs are currently in the process of joining the project and will enter patients in the database once they receive ethical approval. Data collected annually will allow assessment of the clinical outcomes of these patients.

\section{METHODS}

The Canadian HTPN registry is supported by the Canadian Society of Clinical Nutrition. The HTPN registry is Web sitebased and designed to collect information on the following topics: demographics, gastrointestinal anatomy, indications for HTPN, nutritional assessment (including weight, height and body mass index), vascular access and complications of HTPN. Particular complications of interest included central venous catheter infections, hospitalizations, mortality, liver disease and MBD. The patient's quality of life (QOL), as assessed by the patient's primary caregiver using the Karnofsky performance scale, was also documented.

The nine largest HTPN programs in Canada were contacted and invited to participate in the HTPN registry. HTPN programs and their team members were asked to sign a participating agreement and obtain institutional research ethics board approval. After ethical approval, HTPN programs received instructions and passwords that allowed access to the registry. Throughout the process, technical support was provided.

Each patient was then assigned a code to maintain confidentiality, and an electronic record was created on the Web site for each patient. Data were entered using the patients' medical records, either directly into the Web site registry or on case report forms, subsequently used for data entry. Test results or medical events documented over a one-year period were entered and then downloaded into a Microsoft Excel (Microsoft Corp, USA) spreadsheet. Data from the spreadsheet were then imported into the statistical software program SPSS (SPSS Inc, USA) for further analysis. All participating patients provided informed consent for chart review. None of the HTPN patients approached for the study refused to consent.

\section{Statistical analysis}

First, descriptive statistics were conducted for the total cohort and for the subgroups. Pearson correlation coefficients were performed between continuous variables, and Spearman correlation coefficients were used for categorical variables. Unpaired $t$ tests and $\chi^{2}$ tests were conducted when appropriate. The statistical software package utilized was SPSS. Results were expressed as the mean \pm SD. $\mathrm{P}<0.05$ was considered statistically significant.

\section{Population}

\section{RESULTS}

Between 2004 and 2006, nine HTPN programs in Canada were contacted to participate in the Canadian HTPN Web site registry. Eight programs registered with the Web site registry, and five of these programs, including the three largest HTPN programs, entered data on 150 patients. Three of the five programs entered complete data on all patients currently receiving HTPN. The other two programs were at varying stages of data entry. This constituted $37.5 \%$ of the estimated number of HTPN patients in Canada $(\mathrm{n}=400)$. Among those entered, 55 patients (37.9\%) were male and $90(62.1 \%)$ were female. The mean $( \pm \mathrm{SD})$ age was $53.0 \pm 14.0$ years (range 19 to 78 years). The mean duration that patients were on HTPN was $70.1 \pm 78.1$ months; 98 patients $(65.3 \%)$ received HTPN for longer than one year. The mean body mass index before starting HTPN was $19.8 \pm 5.0 \mathrm{~kg} / \mathrm{m}^{2}$ and increased significantly with the administration of TPN $\left(21.5 \pm 3.7 \mathrm{~kg} / \mathrm{m}^{2} ; \mathrm{P}<0.001\right)$. The primary indication for HTPN was short bowel syndrome (SBS) in over $60 \%$ of the cases (Table 1). The most common etiology of SBS in the population was Crohn's disease in 47 patients $(51.1 \%)$, followed by mesenteric ischemia in 22 patients (23.9\%). Other indications included pseudo-obstruction, mucosal disease, fistulas, cancer, unexplained nausea and vomiting, and mechanical obstruction. On average, patients infused HTPN for over $12 \mathrm{~h}$ per day, five to six days per week. TPN prescription, describing volume, energy and macronutrient composition, is reported in Table 2. 
TABLE 2

Home total parenteral nutrition (HTPN) prescription daily average

\begin{tabular}{lc}
\hline Category & $\begin{array}{c}\text { Prescription daily average } \\
\text { (mean } \pm \text { SD) }\end{array}$ \\
\hline Days per week on HTPN & $5.73 \pm 1.58$ \\
Hours of HTPN infused per day & $12.25 \pm 1.55$ \\
Amount of energy infused, kcal/kg & $22.17 \pm 9.17$ \\
Dextrose $(\mathrm{g} / \mathrm{kg})$ & $3.85 \pm 1.55$ \\
Dextrose $(\mathrm{g} / \mathrm{day})$ & $298.66 \pm 81.35$ \\
Protein $(\mathrm{g} / \mathrm{kg})$ & $1.01 \pm 0.35$ \\
Protein $(\mathrm{g} / \mathrm{day})$ & $65.55 \pm 20.59$ \\
Lipid $(\mathrm{g} / \mathrm{kg})$ & $0.66 \pm 0.28$ \\
Lipid $(\mathrm{g} / \mathrm{day})$ & $40.26 \pm 15.8$ \\
Volume $(\mathrm{mL} /$ day) & $1938.59 \pm 786.85$ \\
\hline
\end{tabular}

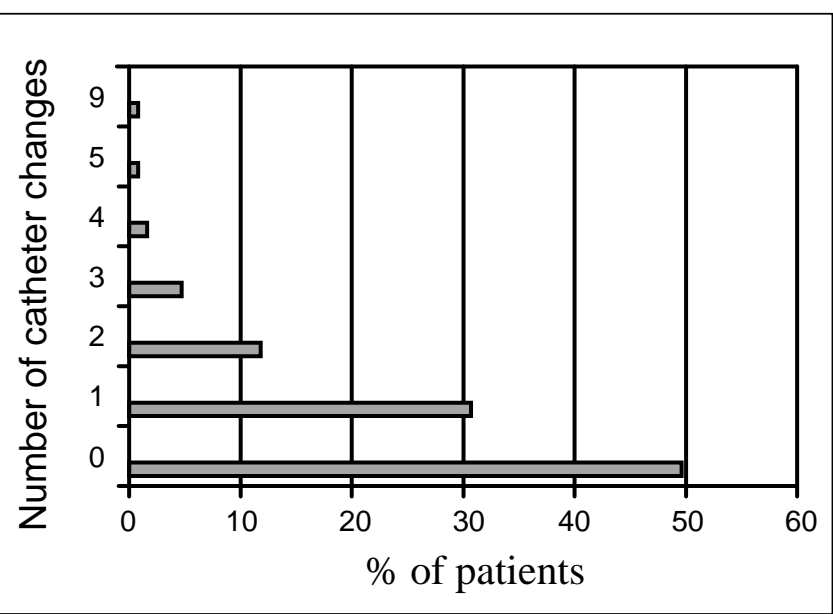

Figure 1) Annual number of catheter changes

\section{Clinical issues related to TPN}

Central venous catheter: Data regarding the central venous catheter were available for 142 patients. TPN was infused via a tunnelled catheter $(\mathrm{n}=96,67.6 \%)$, a peripherally inserted central catheter $(n=24,16.9 \%)$ or an implanted catheter $(n=21$, $14.8 \%)$. The majority of catheters were single lumen $(n=101$, $71.3 \%)$. The remainder were double lumen (28.7\%). Forty patients $(28.6 \%)$ had at least one episode of catheter sepsis over the past year (range of one to six episodes). Patients with a double-lumen catheter had significantly more episodes of catheter sepsis per patient per year than those with singlelumen catheters $(0.91 \pm 1.52$ versus $0.42 \pm 0.87$, respectively; $\mathrm{P}=0.025)$. Approximately $50 \%$ of patients had at least one catheter change over the past year (Figure 1), primarily for episodes of sepsis, catheter occlusion and catheter breakage (Figure 2).

Abnormal liver enzymes and liver disease: Data regarding liver enzymes and liver disease were available for 135 patients. Patients had to be clinically stable (ie, without being in the hospital or without presenting with line sepsis), and the most recent bloodwork needed to show consistently stable, elevated liver enzymes for at least four months. Other causes of elevated liver enzymes were evaluated and excluded. This was also captured in the registry.

Thirty-seven patients (27.4\%) had abnormal liver enzymes, defined as transaminases or alkaline phosphatase levels higher than 1.5 times the upper limit of normal values,

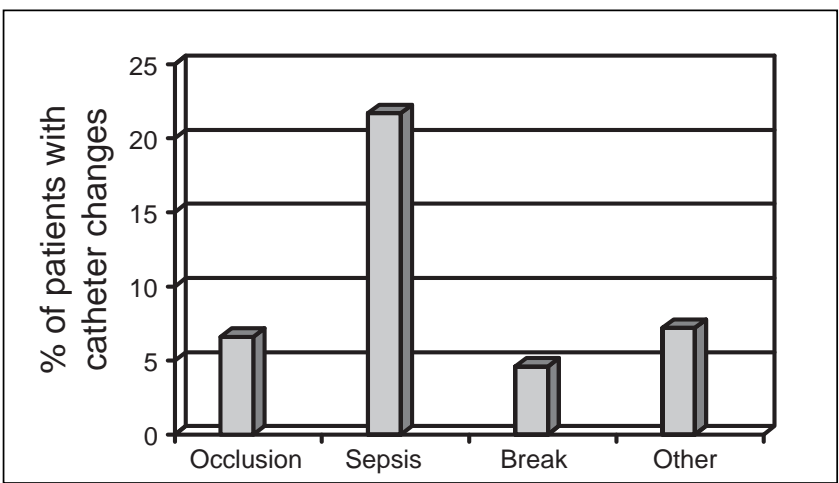

Figure 2) Reasons for catheter changes

TABLE 3

Liver biochemistry of patients with elevated liver enzyme levels and in patients with normal liver enzyme levels

\begin{tabular}{lccc}
\hline Enzyme type & $\begin{array}{c}\text { Elevated liver } \\
\text { enzyme levels } \\
\text { (mean } \pm \text { SD) }\end{array}$ & $\begin{array}{c}\text { Normal liver } \\
\text { enzyme levels } \\
\text { (mean } \pm \text { SD) }\end{array}$ & $\mathbf{P}$ \\
\hline AST, U/L & $74.59 \pm 86.95$ & $36.07 \pm 28.26$ & 0.000 \\
ALT, U/L & $85.4 \pm 133.07$ & $34.64 \pm 21.46$ & 0.002 \\
ALP, U/L & $353.11 \pm 243.75$ & $139.22 \pm 68.45$ & 0.000 \\
Bilirubin, $\mu \mathrm{mol} / \mathrm{L}$ & $35.75 \pm 74.65$ & $11.11 \pm 11.21$ & 0.006 \\
Albumin, g/L & $36.67 \pm 7.06$ & $37.66 \pm 5.29$ & 0.430 \\
\hline
\end{tabular}

ALP Alkaline phosphatase; ALT Alanine aminotransferase; AST Aspartate aminotransferase

or liver disease, defined as evidence of portal hypertension or cirrhosis. Twenty-three patients $(62.2 \%)$ were female. In those reported to have abnormal liver enzymes, the mean number of months on HTPN was $68.34 \pm 71.09$ months, with the primary indication for HTPN being SBS (70.6\%). Other indications included pseudo-obstruction (17.6\%), mucosal disease (2.7\%), fistulas (2.7\%) and cancer (5.4\%). Biochemistry results in patients with elevated liver enzymes and in patients with normal liver enzymes are shown in Table 3. Twelve of the 37 patients with abnormal liver enzymes had liver biopsies. The primary biopsy finding was cholestasis (92\%), followed by steatosis $(8 \%)$. Twenty-five per cent of patients had at least stage 2 fibrosis.

There was no significant difference between patients with abnormal liver enzymes and those with normal liver enzymes with regard to the amount of lipid $(0.63 \pm 0.29 \mathrm{~g} / \mathrm{kg}$ versus $0.67 \pm 0.27 \mathrm{~g} / \mathrm{kg})$ or the amount of protein $(1.08 \pm 0.32 \mathrm{~g} / \mathrm{kg}$ versus $0.98 \pm 0.37 \mathrm{~g} / \mathrm{kg}$ ) administered in the HTPN prescription. Only the prescribed lipid dosage at the time of data entry was known and not the amount received before the development of TPN-related liver disease. However, patients with abnormal liver enzymes received significantly higher dextrose levels than those with normal liver enzymes $(4.40 \pm 1.61 \mathrm{~g} / \mathrm{kg}$ versus $3.63 \pm 1.52 \mathrm{~g} / \mathrm{kg}$, respectively; $\mathrm{P}<0.05$ ), but the amount of dextrose prescribed was within the recommended range. There was a trend toward higher levels of energy administered in patients with abnormal liver enzymes compared with patients with normal enzymes $(24.67 \pm 8.44 \mathrm{kcal} / \mathrm{kg}$ versus $21.37 \pm 9.5 \mathrm{kcal} / \mathrm{kg}$, respectively; $\mathrm{P}=0.07$ ).

Hospitalizations: Data regarding hospitalizations were available for 118 patients. Over the previous year, 74 patients $(62.7 \%)$ had been hospitalized at least once. Fifty-four per cent of all hospitalizations were TPN-related. 
MBD: Data regarding MBD, collected using dual energy $\mathrm{x}$-ray absorptiometry in both the lumbar spine and femoral neck, were available for 69 patients. Sixty per cent of the patients had MBD, according to the criteria defined by the World Health Organization for osteoporosis and osteopenia. Sixtysix per cent of those patients were female, with a mean age of $54.4 \pm 13.3$ years. The average time that patients received HTPN was $87.9 \pm 91.8$ months. The primary indication for HTPN in patients with MBD was SBS (77.1\%). Other indications included pseudo-obstruction $(8.3 \%)$, mucosal disease (10.4\%) and cancer (4.2\%).

Forty-six per cent of patients had osteoporosis, and $18 \%$ had osteopenia in the lumbar spine. In the femoral neck, $12.7 \%$ and $18 \%$ of patients had either osteoporosis or osteopenia, respectively. Only eight patients with osteoporosis were receiving bisphosphonate therapy. No correlation between the $\mathrm{T}$ score and various aspects of the HTPN prescription (amino acid, months on HTPN, calcium, magnesium and phosphate) were identified.

\section{QOL of patients on HTPN}

The QOL of patients on HTPN was assessed by the Karnofsky score. The Karnofsky performance score ranges from zero to 100 , where zero indicates that a patient is deceased and 100 indicates a normally functioning patient with no evidence of active disease. It was designed to measure the level of patient activity and medical care requirements. This score has been validated as a gross clinical estimate of performance in a wide variety of diseases. The Karnofsky score was measured by the member of the HTPN team who knew the patient best. The HTPN patients in the present study had a mean Karnofsky score of 63, indicating that most patients were able to care for most of their needs, although occasional assistance was required.

\section{DISCUSSION}

The present study was the first to report on the demographics, indications and complications of long-term HTPN in the Canadian population. While the results did not include the entire HTPN patient population, it did include more than one-third of the estimated HTPN patients in Canada, because we reported on 150 of an estimated 400 patients (37.5\%) receiving HTPN. These 150 patients were monitored by one of five registered programs from three different provinces (British Columbia, Ontario and Alberta), and therefore, they constituted a good population sample. However, it is important to note that the sample came from large academic centres, and that differences regarding demographics and complications may be present in smaller programs based in community centres.

Parenteral nutrition is a life-saving, but complex, invasive and expensive, therapy (2-5). The total annual cost for HTPN therapy is not precisely known, but the nutrient solution and infusion equipment alone account for US $\$ 70,000$ to US $\$ 120,000$ per year (3). In Canada, the cost is between $\$ 60,000$ and $\$ 100,000$ per year. Monitoring and management of complications require additional costs and are significant, especially if repeated hospitalization is required. Hospitalization for a serious complication, such as sepsis, may cost between US $\$ 10,000$ and US $\$ 50,000$ (6), and has been estimated to be the same in Canada. Therefore, it is important to document the appropriateness, as well as the complications, related to HTPN.
The Canadian HTPN population and HTPN-related complications in the present study were similar to those reported in Europe (5). However, in the US (6), the duration of HTPN was less than one year for most patients, likely reflecting underlying diseases such as malignancy. Because malignancy represented less than $10 \%$ of the indications for HTPN in Canada, it is not surprising that the duration of HTPN requirement was higher than in the US.

The top two indications for HTPN in the present study included SBS resulting from Crohn's disease and mesenteric ischemia, followed by intestinal pseudo-obstruction. These indications are similar to those reported in previous studies $(2,9,10)$. However, in some countries (6), possibly due to cultural differences, HTPN is often prescribed for malignancies, while this is not the case in other countries (11-13). Violante et al (14) recently evaluated the current use of HTPN in Italy. Over a three-year period, $88 \%$ of new prescriptions of HTPN were for indications of malignancy. At the present time, based on the data entered in the Canadian registry, malignancy accounted for only $7.1 \%$ of HTPN indications.

Single-lumen tunnelled catheters were the most frequently used catheter type for administration of HTPN. This is consistent with other published studies $(15,16)$. A higher rate of infection in patients with double-lumen than with singlelumen catheters was noted. Two prospective studies $(17,18)$ evaluated the risk of multi-lumen versus single-lumen catheters in patients receiving parenteral nutrition in the hospital setting. Neither of those studies found an increased risk of infection with multi-lumen catheters. The patients on TPN were different from the patients on HTPN therapy; the patient population was hospitalized and therefore received nursing care for their central catheter, and parenteral nutrition was prescribed for a shorter duration. To our knowledge, no studies were conducted on HTPN patients requiring a multi-lumen catheter.

In our population sample, over $60 \%$ of patients had MBD. This was consistent with one recent study (19) that suggested a prevalence of MBD of $67 \%$ in patients receiving HTPN. Studies $(20,21)$ have shown a high prevalence of both osteoporosis and osteomalacia, attributed directly to the administration of HTPN.

Multiple parenteral nutrition factors may contribute to MBD. These factors include calcium, vitamin D and phosphate deficiencies, aluminum toxicity, acidosis, vitamin D toxicity and amino acid infusions (22-25). However, the concept of HTPN-related MBD was recently challenged by one study. Cohen-Solal et al (19) showed that HTPN had no deleterious effect on cortical bone, and actually improved bone formation in patients with adult-onset intestinal disease.

Despite this one study (19), the American Society for Parenteral and Enteral Nutrition safe practice guidelines suggest optimizing the HTPN solution and monitoring a patient's bone density to prevent or reduce the risk of MBD (26). Unfortunately, bone density measurements were not performed as regularly as they should have been in our HTPN population - only $46 \%$ of HTPN patients had their bone density measured. However, we did not find any correlation between components of the HTPN prescription and MBD, suggesting that HTPN prescription was appropriate. Therefore, monitoring bone density in our HTPN patient population should be improved, because those diagnosed with $\mathrm{MBD}$ can benefit from intravenous bisphosphonate 
therapy $(27,28)$, although this has not been reported by others (29).

One-quarter of our patients had elevated liver enzymes. Liver biopsies performed in a subset of patients showed that the most frequent cause was TPN-related cholestasis. The prevalence of elevated liver enzymes in our study was lower than that reported by Cavicchi et al (30), who prospectively followed 90 patients with chronic intestinal failure who were receiving HTPN for a mean duration of 45 months. In that study, $65 \%$ of patients developed chronic cholestasis, defined as more than 1.5 times the upper limit of normal levels for two of either bilirubin, gamma glutamyl transferase or alkaline phosphatase. Thirty-seven patients (41.5\%) developed complicated HTPN-related liver disease, defined as extensive fibrosis or cirrhosis after a mean duration of 26 to 77 months of HTPN therapy. Subsequently, six patients (22\%) died from their liver disease. The prevalence of complicated liver disease was calculated to be $26 \%$ at two years, and $50 \%$ at six years. One possible difference between the present study's patient population and the study's population reported by Cavicchi et al (30) was the amount of lipid emulsion prescribed. Based on the data from the Canadian registry, the amount of lipid prescribed was less than $1 \mathrm{~g} / \mathrm{kg}$. On the other hand, in the study by Cavicchi et al (30), a significant proportion of patients received more than $1 \mathrm{~g} / \mathrm{kg}$ of lipid emulsion and this correlated significantly with liver disease. Retrospective studies $(30,31)$ have also implicated excessive lipid administration in the pathogenesis of TPN-related liver disease. A reduction in lipid administration to less than $1 \mathrm{~g} / \mathrm{kg}$ resulted in improvement in liver function tests and platelet counts (32). Hence, our HTPN lipid prescribing practice was within the recommended dosages, perhaps partially accounting for the lower rates of liver disease in our population. Further prospective studies of the Canadian population are required to assess this important outcome.

QOL, determined by the Karnofsky score at the time of data entry, was given a mean score of 63 , which indicated that most patients required occasional assistance, although they were able to care for most of their needs. Several studies have evaluated QOL in HTPN patients. However, the instruments used to study QOL have either been generic questionnaires or nonvalidated tools in the HTPN population. Patients receiving HTPN have a poorer QOL than normal individuals, with limitations noted in sleep patterns and awakening at night due to frequent urination and equipment processes during HTPN infusion (33). One systematic review showed that patients with nonmalignant indications for HTPN had reasonable to good QOL (34). It appears that patients with severe Crohn's disease have usually come to terms with limitations in their lifestyle and often note an improvement in QOL when started on HTPN. This is in contrast to those with a mesenteric vessel occlusion $(35,36)$ who experience a sudden dramatic change in lifestyle.

The present Canadian HTPN registry study was unique because it was the first study to capture the demographics and complications of HTPN in Canada. However, there were some limitations to the study. Not all HTPN patients were entered into the database, and as a consequence, the results were based on a sample of 150 patients, representing slightly more than one-third of the estimated HTPN population. These results may not be generalizable to the entire HTPN population in Canada. Participating centres were those with established HTPN programs. Consequently, patients from programs based in small or nonacademic centres were not included. These centres may have had different health care resources and types of medical or surgical practices. Each HTPN program was responsible for entering their own patients. As a consequence, there may have been inconsistencies among HTPN programs in the way the data were entered because of the number of people involved. To minimize this problem and standardize the process, the investigators organized annual meetings held during the Canadian Society for Clinical Nutrition conferences (2003 to 2006) to explain the Web site and discuss data entry. In addition, there were frequent communications via e-mail to answer questions. Due to budget restriction, data entry was not performed twice or repeated by a data analyst. Some patients had incomplete data entry, either because the data were not available or because measurements were not performed. However, we cannot exclude a selection bias in the way the patients were selected or the way data were entered. The data were entered on a voluntary basis by busy allied health professionals who were highly specialized and very invested in the care of HTPN patients. Incomplete data entry was likely due to lack of time rather than interest or selection bias. This was a cross-sectional study; hence, data regarding mortality were not available. As more centres update the database in a prospective manner, clinical outcomes, including mortality, will be obtained.

\section{CONCLUSIONS}

There have been no data on the HTPN population in Canada. Considering that HTPN is an expensive therapy with associated serious complications, a Canadian HTPN registry is important to document appropriateness of HTPN, indications, prescriptions and monitoring to prevent or manage these complications and maximize the QOL of these patients. The registry will help establish standards of practice nationwide and can be used for quality assurance. These preliminary results can be used to identify new areas of research, and to influence health policies and allocation of hospital resources. Areas of research include evaluation of catheter-related risk factors for sepsis, the effect of intravenous bisphosphonate in MBD, QOL and the usefulness of TPN therapy in the oncology population.

Participating Home Total Parenteral Nutrition Programs: British Columbia - Laura Sware RD and Scott Whittaker MD; Edmonton, Alberta (University of Alberta) - Holly Ames RD MSc, Lisa Heighington RN, Marie Hancock RN and Leah Gramlich MD; Hamilton, Ontario (Hamilton Health Sciences Centre) - Anne Childs RN and David Armstrong MD; Toronto, Ontario (St Michael's Hospital) - Clare Meechan RN and Khursheed Jeejeebhoy MBBS MRCP; Toronto, Ontario (Toronto General Hospital) - Ellie Aghdassi PhD, Olivia Saqui BN, Lydia Fairholm RD, Millie Yeung BPharm, Mary Baun BPharm, Jong-Inn Lee MD PhD and Johane Allard MD

\section{REFERENCES}

1. Bakker H, Bozzetti F, Staun M, et al. Home parenteral nutrition in adults: A European multicentre survey in 1997. ESPEN-Home Artificial Nutrition Working Group. Clin Nutr 1999;18:135-40.

2. Howard L, Ament M, Fleming CR, Shike M, Steiger E. Current use and clinical outcome of home parenteral and enteral nutrition therapies in the United States. Gastroenterology 1995;109:355-65.

3. Howard L. Home parenteral nutrition: A transatlantic view. Clin Nutr 1999;18:131-3.

4. Howard L, Ashley C. Management of complications in patients receiving home parenteral nutrition. Gastroenterology 2003;124:1651-61. 
5. Moreno JM, Planas M, de Cos AI, et al. [The year 2003 National Registry of the Home-based Parenteral Nutrition]. Nutr Hosp 2006;21:127-31.

6. Santarpia L, Alfonsi L, Pasanisi F, De Caprio C, Scalfi L, Contaldo F. Predictive factors of survival in patients with peritoneal carcinomatosis on home parenteral nutrition. Nutrition 2006;22:355-60.

7. Howard L. A global perspective of home parenteral and enteral nutrition. Nutrition 2000;16:625-8.

8. Pittet D, Tarara D, Wenzel RP. Nosocomial bloodstream infection in critically ill patients: Excess length of stay, extra costs, and attributable mortality. JAMA 1994;271:1598-601.

9. Ireton-Jones C, DeLegge M. Home parenteral nutrition registry: A five-year retrospective evaluation of outcomes of patients receiving home parenteral nutrition support. Nutrition 2005;21:156-60.

10. Huisman-de Waal G, Naber T, Schoonhoven L, Persoon A, Sanerwein H, van Achterberg T. Problems experienced by patients receiving parenteral nutrition at home: Results of an open interview study. JPEN J Parenter Enteral Nutr 2006;30:215-21.

11. Mughal M, Irving M. Home parenteral nutrition in the United Kingdom and Ireland. Lancet 1986;2:383-7.

12. ESPEN-Home Artificial Nutrition Working Group, Van Gossum A Bakker $\mathrm{H}$, et al. Home parenteral nutrition in adults: A multicentre survey in Europe in 1993. Clin Nutr 1996;15:53-9.

13. Howard L, Heaphey L, Fleming CR, Lininger L, Steiger E. Four years of North American registry home parenteral nutrition outcome data and their implications for patient management. JPEN J Parenter Enteral Nutr 1991;15:384-93.

14. Violante G, Alfonsi L, Santarpia L, et al. Adult home parenteral nutrition: A clinical evaluation after a 3-year experience in a Southern European centre. Eur J Clin Nutr 2006;60:58-61.

15. Moreno JM, Planas M, Lecha M, et al. [The year 2002 national register on home-based parenteral nutrition]. Nutr Hosp 2005;20:249-53.

16. Planas M, Castella M, Moreno JM, et al. [National registry of Home Parenteral Nutrition of the year 2001]. Nutr Hosp 2004;19:139-43.

17. Johnson BH, Rypins EB. Single lumen vs double-lumen catheters for total parenteral nutrition. A randomized, prospective trial. Arch Surg 1990;125:990-2.

18. Ma TY, Yoshinaka R, Banaag A, Johnson B, Davis S, Berman SM. Total parenteral nutrition via multilumen catheters does not increase the risk of catheter-related sepsis: A randomized, prospective study. Clin Infect Dis 1998;27:500-3.

19. Cohen-Solal M, Baudoin C, Joly F, et al. Osteoporosis in patients on long-term home parenteral nutrition: A longitudinal study. J Bone Miner Res 2003;18:1989-94.

20. Pironi L, Labate AM, Pertkiewicz M, et al. Prevalence of bone disease in patients on home parenteral nutrition. Clin Nutr 2002;21:289-96.
21. The TS, Kollee LA, Boon JM, Monnens LA. Rickets in a preterm infant during intravenous alimentation. Acta Paediatr Scand 1983;72:769-71.

22. Bengoa JM, Sitrin MD, Wood RJ, Rosenberg IH. Amino acidinduced hypercalciuria in patients on total parenteral nutrition. Am J Clin Nutr 1983;38:264-9.

23. Lau K, Goldfarb S, Goldberg M, Agus ZS. Effects of phosphate administration on tubular calcium transport. J Lab Clin Med 1982;99:317-24.

24. Cunningham J, Fraher LJ, Clemens TL, Revell PA, Papapoulos SE. Chronic acidosis with metabolic bone disease. Effect of alkali on bone morphology and vitamin D metabolism. Am J Med 1982;73:199-204.

25. Ott SM, Maloney NA, Klein GL, et al. Aluminum is associated with low bone formation in patients receiving chronic parenteral nutrition. Ann Intern Med 1983;98:910-4.

26. Mirtallo J, Canada T, Johnson D, et al; Task force for the Revision of Safe Practices for Parenteral Nutrition. Safe practices for parenteral nutrition. JPEN J Parenter Enteral Nutr 2004;28:S39-70. (Erratum in 2006;30:177).

27. Nishikawa RA, Siepler SE, Siepler JK, et al. Intravenous pamidronate improves bone mineral density in home parenteral nutrition patients. Clin Nutr 2003;22(Suppl 1):s88.

28. Raman M, Aghdassi E, Baun M, et al. Metabolic bone disease in patients receiving home parenteral nutrition: A Canadian study and review. JPEN J Parenter Enteral Nutr 2006;30:492-6.

29. Haderslev KV, Tjellesen L, Sorensen HA, Stann M. Effect of cyclical intravenous clodronate therapy on bone mineral density and markers of bone turnover in patients receiving home parenteral nutrition. Am J Clin Nutr 2002;76:482-8.

30. Cavicchi M, Beau P, Crenn P, Degott C, Messing B. Prevalence of liver disease and contributing factors in patients receiving home parenteral nutrition for permanent intestinal failure. Ann Intern Med 2000;132:525-32.

31. Chan S, McCowen KC, Bistrian BR, et al. Incidence, prognosis, and etiology of end-stage liver disease in patients receiving home total parenteral nutrition. Surgery 1999;126:28-34.

32. Clayton PT, Bowron A, Mills KA, Massoud A, Casteels M, Milla PJ. Phytosterolemia in children with parenteral nutrition-associated cholestatic liver disease. Gastroenterology 1993;105:1806-13.

33. Baxter JP, Fayers PM, McKinlay AW. A review of the quality of life of adult patients treated with long-term parenteral nutrition. Clin Nutr 2006;25:543-53.

34. Richards DM, Deeks JJ, Sheldon TA, Shaffer JL. Home parenteral nutrition: A systematic review. Health Technol Assess $1997 ; 1: 1-59$

35. Herfindal ET, Bernstein LR, Kudzia K, Wong A. A survey of home nutritional support patients. JPEN J Parenter Enteral Nutr 1989;13:255-61.

36. Richards DM, Irving MH. Assessing the quality of life of patients with intestinal failure on home parenteral nutrition. Gut 1997;40:218-22. 


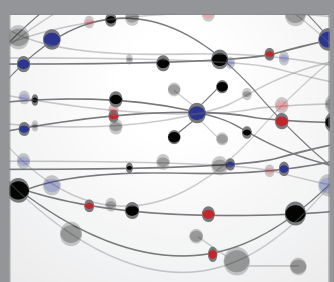

The Scientific World Journal
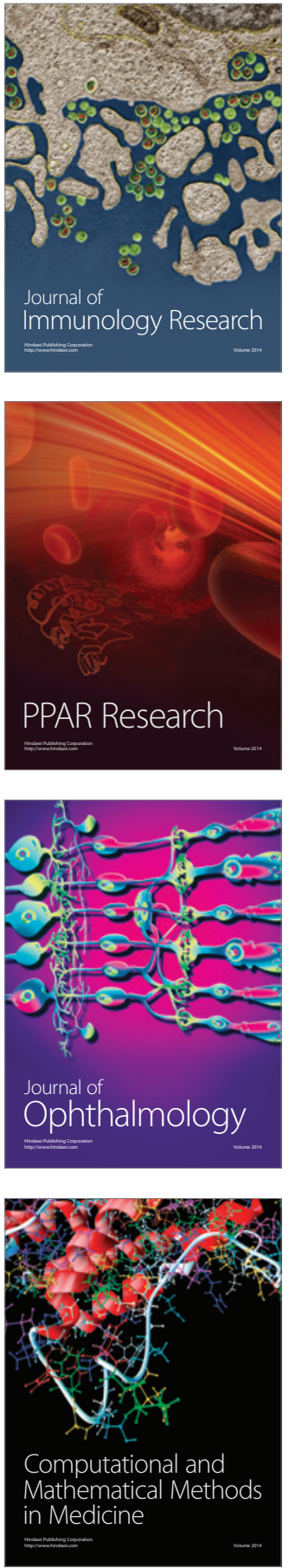

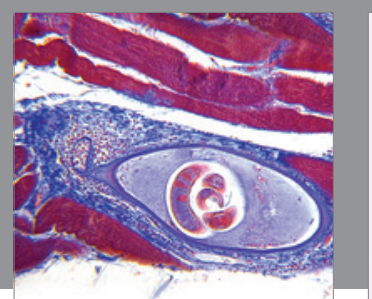

Gastroenterology Research and Practice

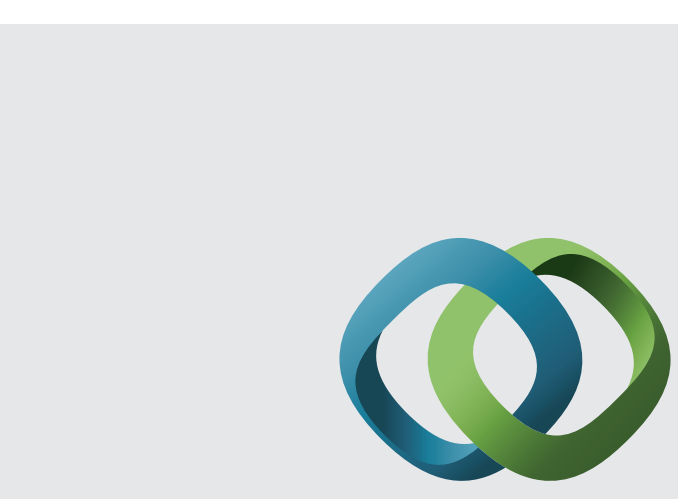

\section{Hindawi}

Submit your manuscripts at

http://www.hindawi.com
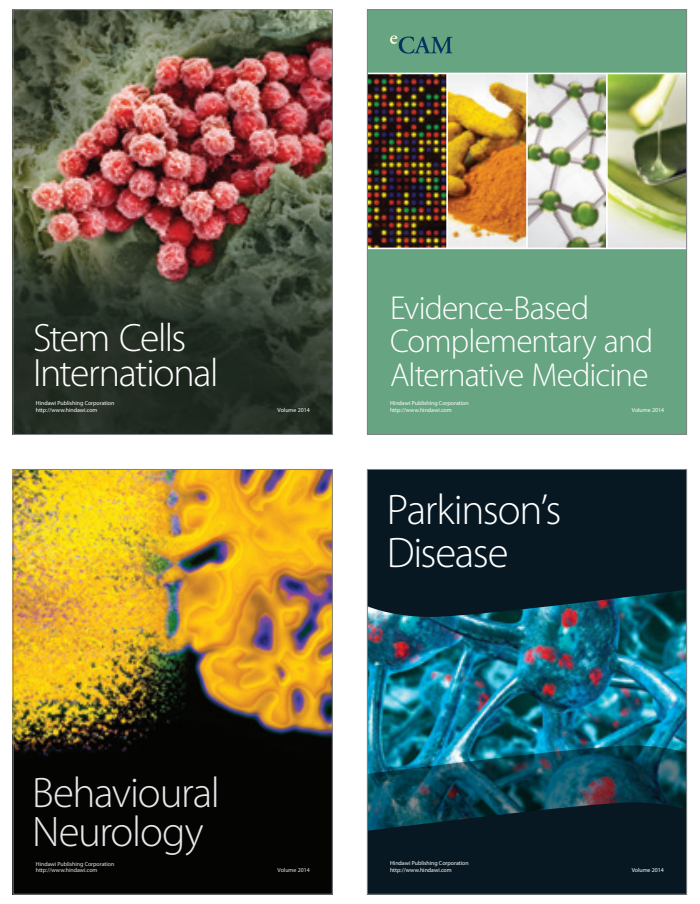
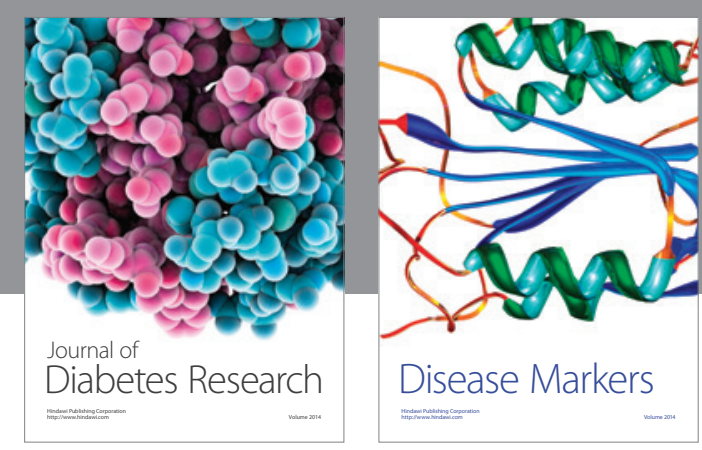

Disease Markers
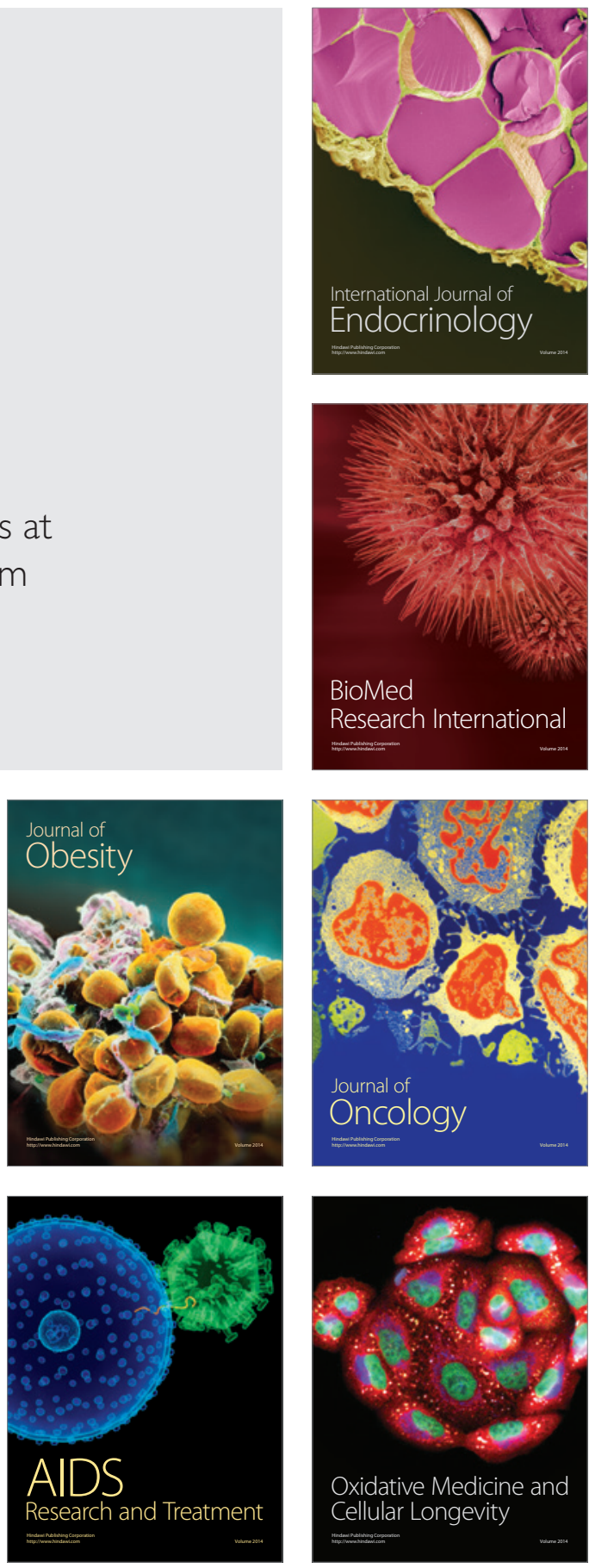